\title{
INTRASPECIFIC KILLING EVENTS IN SIGMODONTINE RODENTS (Oecomys cf. cleberi AND Oligoryzomys nigripes)
}

\author{
Eduardo Guimarães Santos ${ }^{1,2 *}$, Priscilla Lóra Zangrandi ${ }^{1}$, \\ André Faria Mendonça ${ }^{1}$ \& Emerson Monteiro Vieira ${ }^{1}$
}

\begin{abstract}
${ }^{1}$ Universidade de Brasília, Instituto de Ciências Biológicas, Departamento de Ecologia, Laboratório de Ecologia de Vertebrados, CP 04457, Campus Darcy Ribeiro, CEP 70919-970, Brasília, DF, Brazil.

2 Universidade de Brasília, Instituto de Ciências Biológicas, Departamento de Zoologia, Laboratório de Planejamento para Conservação da Biodiversidade , CP 04457, Campus Darcy Ribeiro, CEP 70919-970, Brasília , DF, Brazil.

E-mails: egsantos1991@gmail.com (*corresponding author); priscillalz@gmail.com; mendonca.af@gmail.com; emvieira@unb.br
\end{abstract}

\begin{abstract}
Agonistic events can cause the death of one or more individuals involved and can be an important factor in population structure. The recording of these interactions between small mammals in situ is a difficult task. Here, we describe for the first time two intraspecific killing events occurred inside traps between male sigmodontine rodents belonging to the species Oligoryzomys nigripes and Oecomys cf. cleberi in a Neotropical savanna (Cerrado). We discuss on the nature of the aggression between the males by examining the location of injuries. Our results provide insight into intra-sexual behavioral competition that may occur.
\end{abstract}

Keywords: agonistic behavior; Cerrado; Neotropical savanna; Rodentia; small mammals.

Agonistic events can cause the death of one or more individuals involved and can be an important factor in population structure (Palomares \& Caro 1999, Oliveira \& Pereira 2013). Among fatal events in mammals, infanticide is the most common intraspecific agonistic behavior and has been recorded for several taxa (Hausfater \& Hrdy 1984, Hare 1991, Agrell et al. 1998, Lukas \& Huchard 2014). However, fatal events among adult mammals of the same species are far less documented (but see records for primates, GrosLouis et al. 2003; brown bears, Swenson et al. 2001; ocelots, Thompson 2011; and mountain lions, Galentine \& Swift 2007).

In small mammals, given the difficulty in recording agonistic interactions in situ, almost all knowledge about agonistic interactions is restric- ted to field experiments and laboratory studies (e.g., Wolfe \& Summerlin 1968, Morris \& Grant 1972, Merani \& Lizarralde 1980, Schoener 1983). In cases in which there is interspecific dominance, some studies reported exclusion of the subordinate species involved in the conflict (Miller 1964, Grant 1972, Bonatto et al. 2013a), whereas others suggested avoidance by the subordinate species instead of aggression (Blaustein \& Risser 1976, Petersen \& Helland 2015). Despite the variation in results of encounter trial experiments, studies suggest that the main reason for interspecific agonistic interactions may be competition for food resources (Grant 1972, Munger \& Brown 1981, Krebs 2013, Dupre et al. 2015).

Intraspecific conflict and aggression can be better understood as a consequence of the incre- 
ase in the relative genetic contribution to the population, which is the case of infanticide (Hrdy 1979, Agrell et al. 1998) and male competition for females (Bonatto et al. 2013b, Krebs 2013). For example, in order to attract females to mate, males can increase aggressiveness during the breeding period (Sadleir 1965, Bonatto et al. 2013b). Nonetheless, aggressive behavior is variable among rodent species. During behavioral observations of the dry vesper mouse Calomys musculinus (Rodentia, Cricetidae), males did not demonstrate aggressiveness during the breeding season, in contrast to females, that are territorial (Steinmann et al. 2009). Surprisingly, male prairie voles Microtus ochrogaster (Rodentia, Cricetidae) are more aggressive to females in general after they bond to one, even if they are sexually receptive (Blocker \& Ophir 2016).

We describe two fatal intraspecific events between males of sigmodontine rodents in Cerrado (Neotropical savanna biome) recorded during a long-term project on ecology of small mammals that started in 2009 in central Brazil. One event occurred on October 17, 2013 with two males of Oligoryzomys nigripes, and the other on September 21, 2016 with two males of Oecomys cf. cleberi. During this period, except for the two cases reported here, no multiple captures of male rodents were recorded. To our knowledge there is no record of death caused by either interspecific or intraspecific agonistic interaction inside live-traps, including both standard single-capture live traps (Blaustein \& Rothstein 1978, Bergstrom \& Sauer 1986, Jenkins \& Llewellyn 1981, Drickamer et al. 2003, Christopher et al. 2007,) and multiple capture traps (Getz 1972, Getz et al. 1986, Ganev et al. 2009, McGuire \& Getz 2012).

Both events that we recorded occurred in natural savanna woodland ("cerradão") patches in the Cerrado biome. The patches were located in the Botanic Garden of Brasília (Jardim Botânico de Brasília - JBB), within the Gama e Cabeça de Veado protected area, located approximately 16 km from Brasília, Federal District, Brazil (1552'0.70"S, $\left.\quad 47^{\circ} 49^{\prime} 45.14^{\prime \prime W}\right)$. Details about trapping procedures and site locations are described in Mendonça et al. (2015). In both events, captures occurred in Sherman ${ }^{\circledR}$ live traps $(23 \times 9 \times 8 \mathrm{~cm})$ placed in the understory.
In both cases, bites should have caused the death of the smaller animal. The dead $O$. nigripes had bite wounds on the rump and tail, and the tail was broken into three parts (Figure 1). It weighed $15 \mathrm{~g}$ and had scrotal testes, indicating reproductive activity. The survivor weighed $28 \mathrm{~g}$ and had no marks of injury. Its reproductive condition had not been recorded, but other males of the same size captured at the same period had scrotal testes. In $O$. cf. cleberi, the dead animal had bite wounds on the snout and behind the ear (Figure 2). It weighed $14 \mathrm{~g}$ and had abdominal testes. The survivor had scrotal testes, weighed $16 \mathrm{~g}$ and had no marks of injury.

During this long-term project, the body mass of $O$. nigripes males was $21.6 \pm 4.9 \mathrm{~g}$ (mean $\pm \mathrm{SD}, \mathrm{N}=$ 33). The survivor weighed $6 \mathrm{~g}$ more than this whereas the dead animal was $6 \mathrm{~g}$ below this average. Thus, the determining factor for the victory in the dispute could be body mass, as observed in other studies (English 1932, Howard 1961, Miller 1964). In contrast, body mass of both $O$. cf. cleberi individuals were below the mean for males of this species in the study area (mean \pm SD: $26.5 \mathrm{~g} \pm 6.7 \mathrm{~g} ; \mathrm{N}=173$ ), suggesting both were juveniles or subadults. In addition, the survivor was captured three months after the episode (December 2016) with a larger body size (29 g),
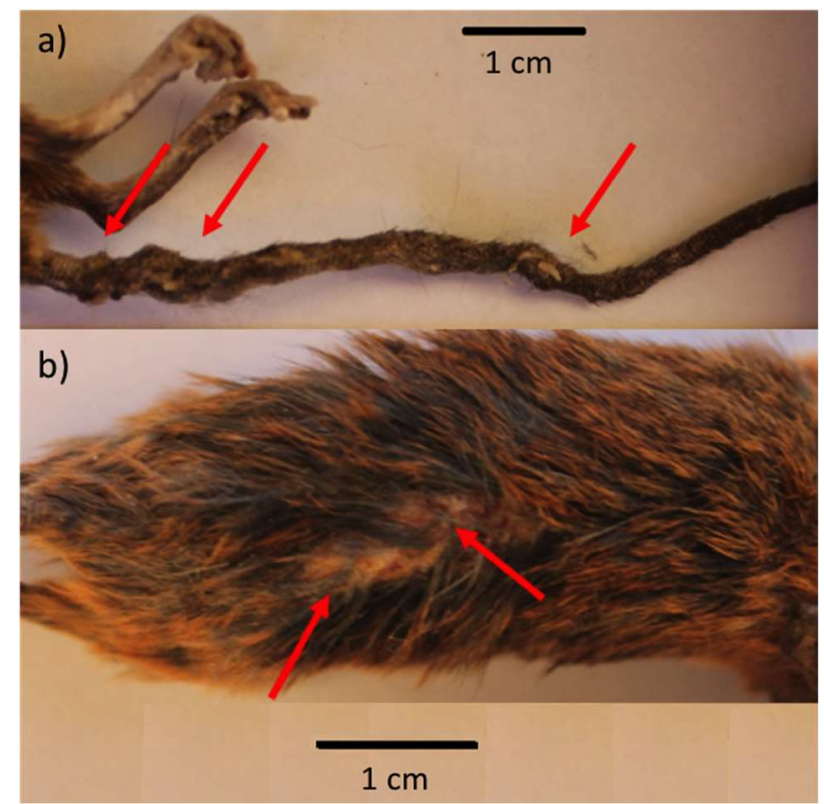

Figure 1. Signs of the intraspecific attack. Male of Blackfooted pygmy rice rat (Oligoryzomys nigripes) found dead inside the live-trap. a) bite marks on the tail, which is broken into three parts; and b) bite marks on the back. 

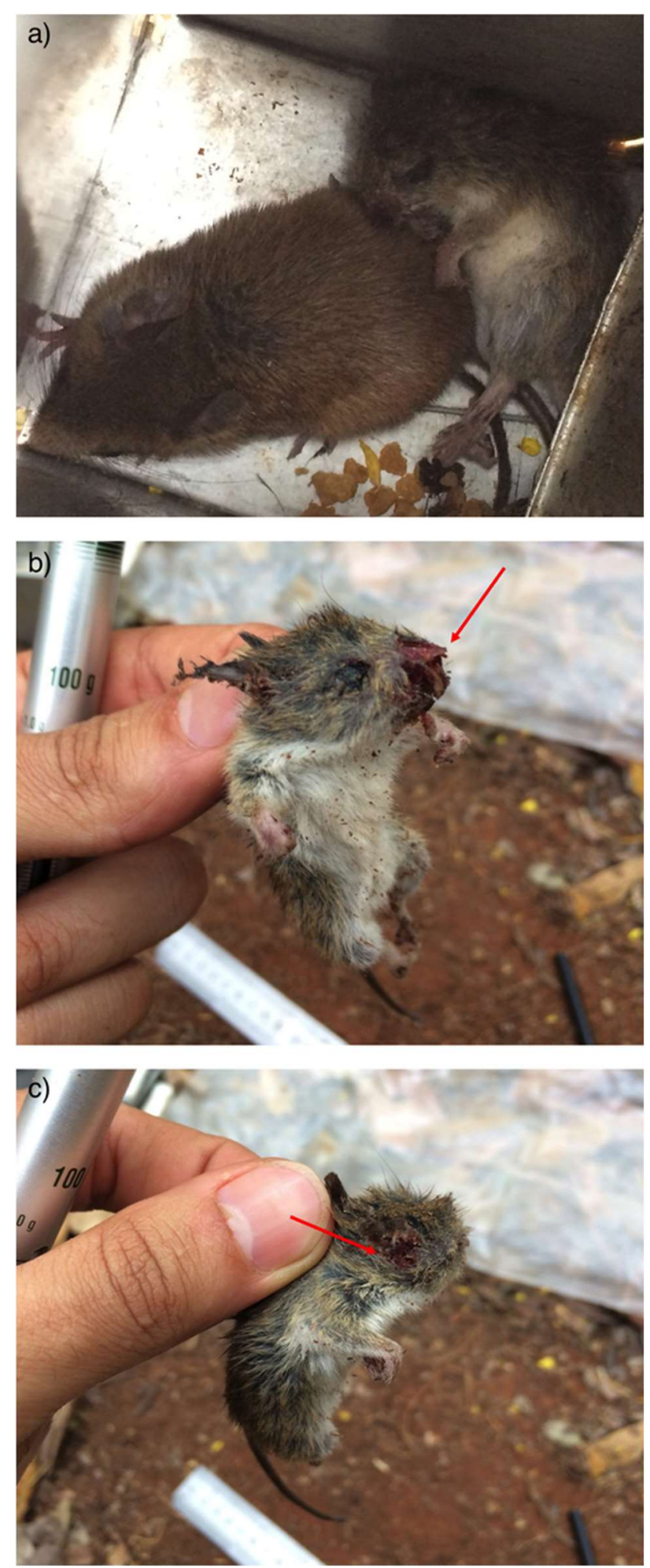

Figure 2. Males of the Cleber's arboreal rice rat (Oecomys cf. cleberi). a) Two individuals inside the Sherman ${ }^{\circledR}$ live-trap; b) dead male with wounds on the snout and c) behind the ear.

indicating that this individual had not reached adult size at the time of the killing event. Thus, intraspecific killing in $O$. cf. cleberi was probably influenced by the breeding status, that may have led the reproductively active male to increased testosterone level and, hence, increased aggressiveness (Barfield et al. 1972, Albert et al. 1986, Boonstra et al. 2001).

Studies describing in detail how agonistic encounters happen enable us to identify patterns that lead to the understanding of this type of interaction. In rodents, bites occur more often on the shoulder and on the side due to common flank attacks and the defensive behavior from the attacked animal of rolling onto its back and kicking the attacker (Blanchard \& Blanchard 1977, Blanchard et al. 1985). That is probably the case of $O$. cf. cleberi, since the dead male had injuries behind the ear, and close to the shoulder (Figure 2). Moreover, the animal had a partially eaten snout, which is commonly observed in these defensive situations among rodents (Blanchard et al. 1977, Adams 1979). On the other hand, the dead $O$. nigripes had wounds on the tail and rump (Figure 1), which may indicate no attempt of selfdefense, most probably due to the near two-fold difference in body mass between males.

Normally the agonistic behavior characterized by social attacks among rodents probably does not lead to death. In house mice (Mus musculus; Rodentia, Muridae), for example, the immediate response to an attack and chase is usually evasion and flight, and seldom an attack in response (Miczek et al. 1998). This type of behavior was also observed in studies of dominance in rodents such as in Azara's grass mouse (Akodon azarae; Rodentia, Cricetidae) and in the small vesper mouse (Calomys laucha; Rodentia, Cricetidae) (Courtalon et al. 2003). However, in the cases presented here, the animals were confined to a limited space. In these episodes, the aggression could be intensified and the attacked animals eventually died. We could not confirm if the cause of death was stress or the injuries themselves.

Despite extensive literature on intraspecific agonistic behaviors for rodents of the Northern Hemisphere (e.g., Sadleir 1965, Scott 1966, Munger \& Brown 1981, Wolff et al. 1983, Petersen \& Helland 2015, Blocker \& Ophir 2016), few studies have been conducted on sigmodontine rodents (e.g., Courtalon et al. 2003, Steinmann et al. 2009, Bonatto et al. 2013a, Petersen \& Helland 2015, Bonatto et al. 2017). Furthermore, this is the first study that reports intraspecific killing in free-living 
sigmodontines trapped in the same live-trap. Although we did not have direct observations of agonistic interactions, the individual characteristics and injuries helped us better understand the dynamics of these events. In the episode with $O$. nigripes, the heavier male had clearly an advantage over the other. However, in the case of $O$. cf. cleberi, body mass was not the determining factor, but the breeding condition. The potential reproductive activity may have given one male more aggressiveness and maybe even more strength than the other of similar size, but still reproductively inactive. In addition, we can speculate that mass of individuals determines how the occurrence of the agonistic behavior is. When the difference in body mass was large, the attacked animal tried to escape more than to defend itself, whereas when individuals were similar in body mass, injuries suggest an attempt to self-defense by the loser. In both cases, the fighting advantage was greater for the winners, which did not suffer any injuries at all.

\section{ACKNOWLEDGMENTS}

We are thankful to all undergraduate and graduate students who provided valuable help in our fieldwork. This work was supported by grant from the Brazilian State Funding Agency of Federal District to EMV (FAPDF - 193.000.914/2015). While conducting this study PLZ received a scholarship from the National Council for Scientific and Technological Development (CNPq); EMV received a personal research grant from $\mathrm{CNPq}\left(\mathrm{N}^{\circ}\right.$ 308992/2013-0); and AFM received a post-doctoral fellowship from the Brazilian Federal Agency for Support and Evaluation of Graduate Education (PNPD/CAPES). We thank the permission granted by the Botanic Garden of Brasília (JBB) for conducting the fieldwork. We also thank Thiago Marques for the photographs of the Oligoryzomys nigripes specimen and Rudy Boonstra for helpful suggestions on an earlier version of the manuscript.

\section{REFERENCES}

Adams, D. B. 1979. Brain mechanisms for offense, defense, and submission. The Behavioral and
Brain Sciences, 2, 201-241. DOI: 10.1017/S0140 525X00061926

Agrell, J., Wolff, J. O., \& Ylönen, H. 1998. Counterstrategies to infanticide in mammals: costs and consequences. Oikos, 83(3), 507-517. DOI: 10.2 $307 / 3546678$

Albert, D. J., Walsh, M. L., Gorzalka, B. B., Siemens, Y., \& Louie, H. 1986. Testosterone removal in rats results in a decrease in social aggression and a loss of social dominance. Physiology and Behavior, 36(3), 401-407. DOI: 10.1016/00319384(86)90305-7

Barfield, R. J., Busch, D. E., \& Wallen, K. 1972. Gonadal influence on agonistic behavior in the male domestic rat. Hormones and Behavior, $3(3)$, 247-259. DOI: $10.1016 / 0018-$ 506X(72)90038-4

Bergstrom, B. J., \& Sauer, J. R. 1986. Social traveling inferred from multiple captures: testing assumptions. The American Midland Naturalist, 115(1), 201-203. DOI: 10.2307/2425 851

Blanchard, R. J., \& Blanchard, D. C. 1977. Aggressive behavior in the rat. Behavioral Biology, 21(2), 197-224. DOI: 10.1016/S0091-67 73(77)90308-X

Blanchard, R. J., Blanchard, D. C., Takahashi, T., \& Kelley, M. J. 1977. Attack and defensive behaviour in the albino rat. Animal Behaviour, 25(PART 3), 622-634. DOI: 10.1016/00033472(77)90113-0

Blanchard, R. J., Pank, L., Fellows, D., \& Blanchard, D. C. 1985. Conspecific wounding in freeranging R. norvegicus from stable and unstable populations. The Psychological Record, 35, 329335. DOI: 10.1007/BF03395855

Blaustein, A. R., \& Risser, A. C. J. 1976. Interspecific interactions between three sympatric species of kangaroo rats (Dipodomys). Animal Behaviour, 24(2), 381-385. DOI: 10.1016/S0003-3472(76)80 047-4

Blaustein, A. R., \& Rothstein, S. I. 1978. Multiple captures of Reithrodontomys megalotis: social bonding in a mouse? The American Midland Naturalist, 100(2), 376-383. DOI: 10.2307/2424 837

Blocker, T. D., \& Ophir, A. G. 2016. A preference to bond? Male prairie voles form pair bonds even in the presence of multiple receptive females. 
Animal Behaviour, 122, 89-97. DOI: 10.1016/ j.anbehav.2016.10.007

Bonatto, F., Coda, J., Priotto, J., \& Steinmann, A. 2013a. Inter-female territorial behavior in pampean grassland mouse, Akodon azarae (Cricetidae: Sigmodontinae). Mastozoología Neotropical, 20(2), 367-372.

Bonatto, F., Coda, J., Gomez, D., Priotto, J., \& Steinmann, A. 2013b. Inter-male aggression with regard to polygynous mating system in Pampean grassland mouse, Akodon azarae (Cricetidae: Sigmodontinae). Journal of Ethology, 31, 223-231. DOI: 10.1007/s10164-0130370-4

Bonatto, F., Priotto, J., Coda, J., \& Steinmann, A. R. 2017. Female intrasexual territoriality and its potential adaptive significance: the Pampean grassland mouse as an ecological model species. Ethology, 123(3), 230-241. DOI: 10.1111/eth.1 2592

Boonstra, R., McColl, C. J., \& Karels, T. J. 2001. Reproduction at all costs: the adaptive stress response of male artic ground squirrels. Ecology, 82(7), 1930-1946. DOI: 10.1890/0012-9658(20 01)082[1930:RAACTA]2.0.CO;2

Christopher, C. C., Barrett, G. W., Christopher, C. C., \& Barrett, G. W. 2007. Double captures of Peromyscus leucopus (white-footed mouse) and Ochrotomys nuttalli (golden mouse). Southeastern Naturalist, 6(3), 407-412. DOI: 10. 1656/1528-7092(2007)6[407:DCOPLW]2.0.CO;2

Courtalon, P., Dolcemascolo, A., Troiano, V., Álvarez, M. R., Busch, M., Martín, R., Courtalon, P., Dolcemascolo, A., Troiano, V., Álvarez, M. R., \& Busch, M. 2003. Inter and intraspecific relationships in Akodon azarae and Calomys laucha (Rodentia, Sigmodontinae) in pampean agroecosystems. Mastozoología Neotropical, 10(1), 27-39.

Drickamer, L. C., Wagner, D. M., \& Robinson, S. A. 2003. Double captures of house mice (Mus musculus) with information on genetic relatedness. The American Midland Naturalist, 150(2), 308-320. DOI: 10.1674/0003-0031(2003)1 50[0308:DCOHMM]2.0.CO;2

Dupre, S. I., Lambert, T. D., Adler, G. H., Hegde, L. M., \& Kennedy, E. H. 2015. Aggressive and investigative behaviors of two sympatric species of echimyid rodents, Proechimys semispinosus and Hoplomys gymnurus, in Central Panama.
Ethology Ecology \& Evolution, 1-8. DOI: 10.10 80/03949370.2015.1078414

English, P. F. 1932. Some habits of the pocket gopher, Geomys breviceps breviceps. American Society of Mammalogists, 13(2), 126-132. DOI: $10.2307 / 1374048$

Galentine, S. P., \& Swift, P. K. 2007. Intraspecific killing among mountain lions (Puma concolor). The Southwestern Naturalist, 52(1), 161-164. DOI: 10.1894/0038-4909(2007)52[161:IKAMLP]2. 0.CO;2

Ganev, I. V., Solomon, N. G., Lucia, K. E., \& Keane, B. 2009. Multiple captures of adult prairie voles are correlated with residency status and genetic parentage. Journal of Mammalogy, 90(3), 696703. DOI: 10.1644/08-MAMM-A-198R1.1

Getz, L. L. 1972. Social structure and aggressive behavior in a population of Microtus pennsylvanicus. Journal of Mammalogy, 53(2), 310-317. DOI: 10.2307/1379167

Getz, L. L., Cole, F. R., \& Verner, L. 1986. Effectiveness of multiple-capture live traps for field behavioral studies of microtine rodents. Bulletin of the Psychonomic Society, 24(1), 7274. DOI: 10.3758/BF03330507

Grant, P. R. 1972. Interspecific competition among rodents. Annual Review of Ecology and Systematics, 3(1), 79-106. DOI: 10.1146/annure v.es.03.110172.000455

Gros-Louis, J., Perry, S., \& Manson, J. H. 2003. Violent coalitionary attacks and intraspecific killing in wild white-faced capuchin monkeys (Cebus capucinus). Primates, 44(4), 341-346. DOI: $10.1007 / \mathrm{s} 10329-003-0050-\mathrm{z}$

Hare, J. F. 1991. Intraspecific killing of preweaned young in the columbian ground squirrel, Spermophilus columbianus. Canadian Journal of Zoology, 69, 797-800. DOI: 10.1139/z91-115

Hausfater, G., \& Hrdy, S. B. 1984. Infanticide: comparative and evolutionary perspective. New York: Aldine Press: p. 598.

Howard, W. E. 1961. A pocket gopher population crash. Journal of Mammalogy, 42(2), 258-260. DOI: $10.2307 / 1376846$

Hrdy, S. B. 1979. Infanticide among animals: a review, classification, and examination of the implications for the reproductive strategies of females. Ethology and Sociobiology, 40, 13-40. DOI: 10.1016/0162-3095(79)90004-9

Jenkins, S. H., \& Llewellyn, J. B. 1981. Multiple 
captures of Peromyscus: age, sex, and species differences. Journal of Mammalogy, 62(3), 639641. DOI: $10.2307 / 1380416$

Krebs, C. J. 2013. Population fluctuations in rodents. Chicago: University of Chicago Press: p. 296.

Lukas, D., \& Huchard, E. 2014. The evolution of infanticide by males in mammalian societies. Science, 346(6211), 841-844. DOI: 10.1126/science. 1257226

McGuire, B., \& Getz, L. L. 2012. Multiple captures provide evidence of small mammal social behavior. Acta Theriologica, 57, 49-57. DOI: 10. 1007/s13364-011-0051-z

Mendonça, A. F., Bocchiglieri, A., \& Vieira, M. V. 2015. Limb abnormality in a neotropical scansorial marsupial, Gracilinanus agilis (Didelphimorphia: Didelphidae). Mammalia, 80(4), 445-448. DOI: 10.1515/mammalia-20150007

Merani, M. S., \& Lizarralde, M. S. 1980. Akodon molinae (Rodentia Cricetidae), a new laboratory animal: breeding, management and reproductive performance. Laboratory Animals, 14, 129131. DOI: $10.1258 / 002367780780942944$

Miczek, K. A., Thompson, M. L., \& Tornatzky, W. 1998. Short and long term physiological and neurochemical adaptations to social conflict. In: S. Puglisi-Allegra \& A. Oliverio (Eds.), Psychobiology of Stress. pp. 15-30. Dordrecht / Boston / London: Kluwer Academic Publishers.

Miller, R. S. 1964. Ecology and distribution of pocket gophers (Geomyidae) in Colorado. Ecology, 45(2), 256-272. DOI: 10.2307/1933839

Morris, R. D., \& Grant, P. R. 1972. Experimental studies of competitive interaction in a twospecies system. Journal of Animal Ecology, 41(2), 275-290. DOI: 10.2307/3469

Munger, J. C., \& Brown, J. H. 1981. Competition in desert rodents: an experiment with semipermeable exclosures. Science, 211(4481), 510512. DOI: $10.1126 /$ science.211.4481.510

Oliveira, T. G. De, \& Pereira, J. A. 2013. Intraguild predation and interspecific killing as structuring forces of carnivoran communities in South America. Journal of Mammalian Evolution, 21 (4), 427-436. DOI: 10.1007/s10914-013-9251-4
Palomares, F., \& Caro, T. M. 1999. Interspecific killing among mammalian carnivores. The American Naturalist, 153(5), 492-508. DOI: $10.1086 / 303189$

Petersen, M. K., \& Helland, M. J. 2015. Behavioral interactions in Sigmodon fulviventer and $S$. hispidus. Journal of Mammalogy, 59(1), 118-124. DOI: $10.2307 / 1379881$

Sadleir, R. M. F. S. 1965. The relationship between agonistic behaviour and population changes in the deermouse, Peromyscus maniculatus (Wagner). Journal of Animal Ecology, 34(2), 331352. DOI: $10.2307 / 2654$

Schoener, T. W. 1983. Field experiments on interspecific competition. The American Naturalist, 122(2), 240-285. DOI: 10.1086/284133

Scott, J. P. 1966. Agonistic behavior of mice and rats: a review. American Zoologist, 6(4), 683-701. DOI: $10.1093 / \mathrm{icb} / 6.4 .683$

Steinmann, A. R., Priotto, J. W., \& Polop, J. J. 2009. Territorial behaviour in corn mice, Calomys musculinus (Muridae: Sigmodontinae), with regard to mating system. Journal of Ethology, 27, 51-58. DOI: 10.1007/s10164-008-0083-2

Swenson, J. E., Dahle, B., \& Sandegren, F. 2001. Intraspecific predation in Scandinavian brown bears older than cubs-of-the-year. Ursus, 12, 81-92.

Thompson, C. L. 2011. Intraspecific killing of a male ocelot. Mammalian Biology, 76(3), 377379. DOI: $10.1016 /$ j.mambio.2010.10.011

Wolfe, J. L., \& Summerlin, C. T. 1968. Agonistic behavior in organized and disorganized cotton rat populations. Science, 160(3823), 98-99. DOI: 10.1126/science.160.3823.98

Wolff, J., Freeberg, M. H., \& Dueser, R. D. 1983. Interspecific territoriality in two sympatric species of Peromyscus (Rodentia: Cricetidae). Behavioral Ecology and Sociobiology, 12(3), 237-242. DOI: 10.1007/BF00290776

Submitted: 10 December 2017 Accepted: 02 April 2018 Associate Editor: Camila S. Barros 